\title{
Basosquamous Cell Carcinoma Developing from a Renal Transplantation Recipient
}

\author{
Akira Tsukada Taku Fujimura Sadanori Furudate \\ Yumi Kambayashi Akira Hashimoto Setsuya Aiba \\ Department of Dermatology, Tohoku University Graduate School of Medicine, \\ Sendai, Japan
}

\section{Key Words}

Basosquamous cell carcinoma $\cdot$ Immunosuppressive cells $\cdot \mathrm{CD}_{163}{ }^{+} \mathrm{M} 2$ macrophage $\cdot$ Carcinogenesis

\begin{abstract}
We describe a case of basosquamous cell carcinoma arising from a 52-year-old Japanese renal transplantation recipient (RTR). In the present case, we investigated the immunohistochemical profiles of tumor-infiltrating lymphocytes, focusing on cytotoxic granules, granulysin-bearing cells and immunosuppressive cells, such as regulatory $T$ cells and tumor-associated macrophages. Our present study suggests some of the possible mechanisms for the carcinogenesis of cutaneous malignancy in RTRs.
\end{abstract}

\section{Introduction}

The risk factors for non-melanoma skin cancer (NMSC) in renal transplant recipients (RTRs) are related to the dosage and duration of administration of immunosuppressive reagents [1]. Concerning genetic factors, several factors, such as p53 tumor suppressive gene mutations, are responsible for the carcinogenesis of skin carcinomas in RTRs [2]. In general, evaluation of not only the genetic factors, but also the immunological environment is indispensable for the assessment of oncogenesis [3]. In this report, we present a case of basosquamous cell carcinoma developing on the nose of an RTR; immunohistochemical staining focusing on immunosuppressive and immunomodulatory cells was employed. 


\section{Case Report}

A 52-year-old Japanese man visited our outpatient clinic with a 1-month history of a red nodule on his nose. He had undergone renal transplantation 20 years before and, since then, had taken oral cyclosporine. On his initial visit, physical examination revealed a red, dome-shaped, easy-to-bleed nodule on his nose (fig. 1 ). The size was approximately $10 \times 8 \mathrm{~mm}$ in diameter. A biopsy specimen revealed dermal infiltration of the tumor, which was composed of atypical keratinocytes with dyskeratotic cytoplasm and peripheral palisaded basaloid cells (fig. $2 \mathrm{a}$ ). From the above findings, the specimen was diagnosed as basosquamous cell carcinoma arising from an RTR. The lesion was excised with a 1-cm surgical margin. To further investigate the possible mechanisms of the carcinogenesis of RTRs, immunohistochemical staining was employed, especially focusing on cytotoxic T cells and immunosuppressive lymphocytes as we previously reported $[4,5]$. Immunohistochemical staining revealed dense infiltration of CD163+ macrophages and granulysinbearing cells (fig. 2b, d), and scattered IL-17-producing cells (fig. 2c). Few Foxp $3^{\text {hight }}$ cells were detected (data not shown).

\section{Discussion}

In this report, we present a case of basosquamous cell carcinoma on the nose of an RTR. Interestingly, immunohistochemical staining revealed dense infiltration of CD163+ M2 macrophages as well as scattered IL-17-producing cells and granulysin-bearing cells.

Long-term administration of immunosuppressive agents has been thought to be responsible for causing DNA damage that interferes with normal DNA repair mechanisms and deviations in natural immune surveillance [1]. Renal transplantation is associated with an increased incidence of NMSC caused by immunosuppression. Squamous cell carcinoma and basal cell carcinoma, the two major histological types of NMSC, exhibit more aggressive biological and clinical courses in RTRs, with higher rates of recurrence and mortality than in the general population [6]. Compared to these two major NMSC in RTRs, basosquamous cell carcinomas developing from RTRs have been relatively rare [7]. In addition, interestingly, NMSC showed reduced tumor-infiltrating lymphocytes (TILs), compared with conventional NMSC [8]. Therefore, in this report, immunohistochemical staining was employed to investigate the profiles of TILs in the basosquamous cell carcinoma, especially focusing on immunosuppressive cells.

Immunosuppressive cells, such as regulatory T cells (Tregs), myeloid-derived suppressor cells, and M2 macrophages play a role in maintaining the tumor environment $[3,9]$. The high frequency of Tregs in patients with carcinomas reportedly contributes to lymphocyte dysfunction, leading to the suppression of antitumor immune responses [10]. In our present case, few Tregs were detected around the tumor. As a previous report suggested [11], long-term intake of cyclosporine may suppress the proliferation and function of Tregs. Instead of Tregs, numerous CD163+ M2 macrophages were detected in our case, which might be related to the immunosuppressive tumor microenvironment.

The role of suppressive macrophages is currently one area of interest in human carcinogenesis $[4,5,9]$. CD163+ M2 macrophages were recently reported to promote an immunosuppressive environment by the suppression of $\mathrm{T}$ cell activities through various pathways in the tumor-bearing host, and contribute to tumor growth, invasion and metastasis $[3,12,13]$. As our present case contained a number of granulysin- 
bearing cells and IL-17-producing cells, the abrogation of immunosuppressive macrophages might suppress the development of skin cancer in RTRs (fig. 3 ). Since we did not directly assess the suppressive function of these infiltrating M2 macrophages, granulysin-bearing cells, and IL-17-producing cells, further analysis of the mechanisms underlying this phenomenon would offer fundamental insight into the mechanisms of skin cancer in RTRs. Such clarification will need to be addressed in future investigations.

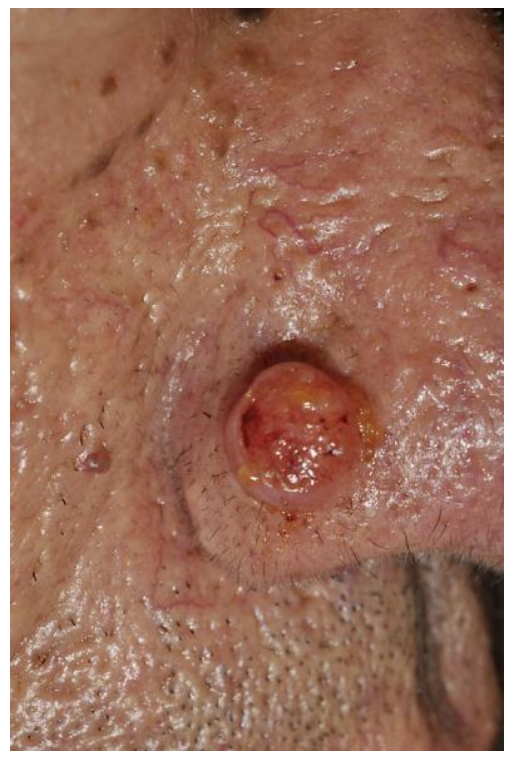

Fig. 1. A red, dome-shaped, $10 \times 8$-mm, easy-to-bleed nodule on the nose. 

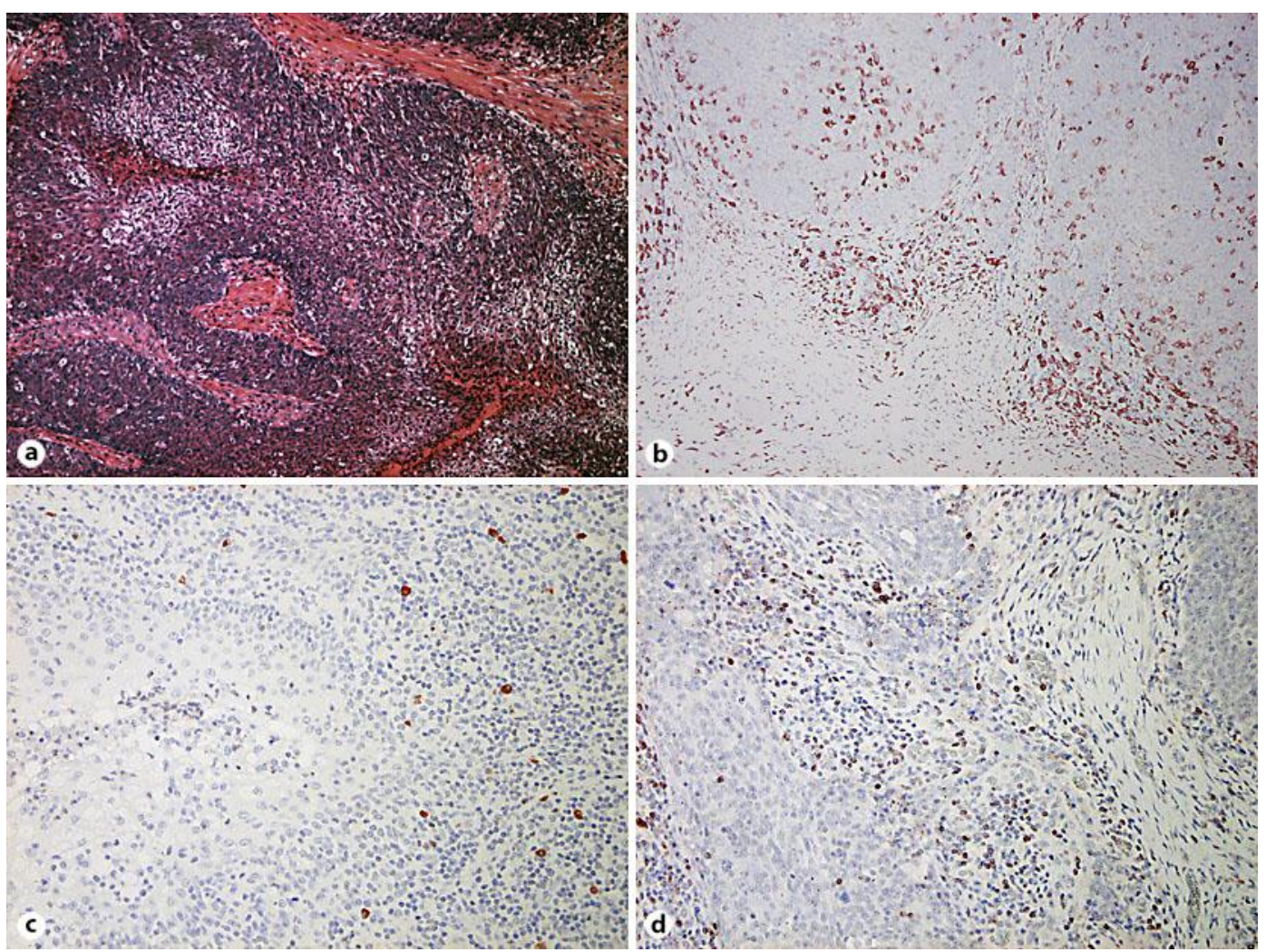

Fig. 2. Dermal infiltration of the tumor, which was composed of atypical keratinocytes with dyskeratotic cytoplasm and peripheral palisaded basaloid cells (a). Paraffin-embedded tissue samples from the patient were stained as follows: the sections were developed with liquid permanent red for CD163 (b), IL-17 (c), and granulysin (d). [Orig. magnif. ×100 (a), ×200 (b-d).] 


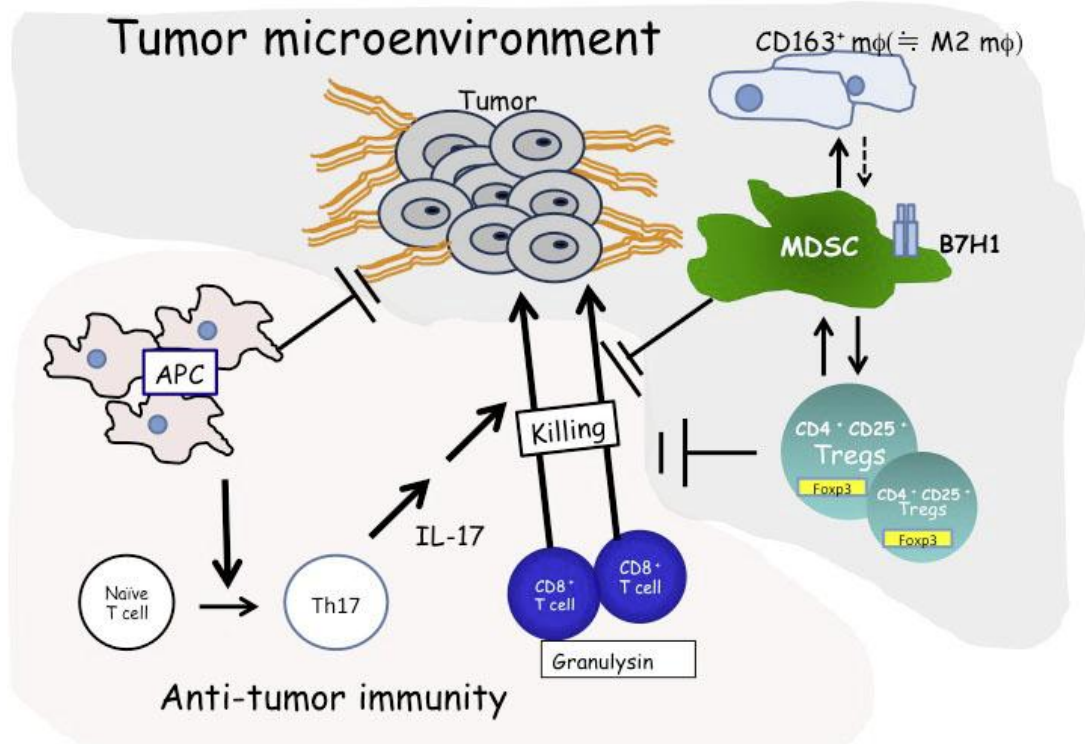

Fig. 3. Together with Tregs, CD163+ M2 macrophages suppress the antitumor immune response against the tumor. In contrast with immunosuppressive lymphocytes, the effector cells and immunomodulatory cells promote antitumor immune response.

\section{References}

1 Zavos G, Karidis NP, Tsourouflis G, Bokos I, Diles K, Sotirchos G, Theodoropoulou E, Kostakis A: Nonmelanoma skin cancer after renal transplantation: a single-center experience in 1,736 transplantations. Int J Dermatol 2011;50:1496-1500.

2 de Graaf YG, Rebel H, Elghalbzouri A, Cramers P, Nellen RG, Willemze R, Bouwes Bavinck JN, de Gruijl FR: More epidermal p53 patches adjacent to skin carcinomas in renal transplant recipients than in immunocompetent patients: the role of azathioprine. Exp Dermatol 2008;17:349-355.

3 Fujimura T, Mahnke K, Enk AH: Myeloid derived suppressor cells and their role in tolerance induction. J Dermatol Sci 2010;59:1-6.

-4 Tsukada A, Fujimura T, Furudate S, Kambayashi Y, Numata Y, Haga T, Hashimoto A, Aiba S: Cutaneous squamous cell carcinoma developing from recessive dystrophic epidermolysis bullosa: a case report and immunohistochemical study. Case Rep Dermatol 2012;4:197-201.

5 Fujimura T, Kakizaki A, Kambayashi Y, Aiba S: Basal cell carcinoma with spontaneous regression: a case report and immunohistochemical study. Case Rep Dermatol 2012;4:125-132.

6 Kasiske BL, Snyder JJ, Gilbertson DT, Wang C: Cancer after kidney transplantation in the United States. Am J Transplant 2004;4:905-913.

-7 Mougel F, Kanitakis J, Faure M, Euvrard S: Basosquamous cell carcinoma in organ transplant patients: a clinicopathologic study. J Am Acad Dermatol 2012;66:e151-e157.

8 Harwood CA, Proby CM, McGregor JM, Sheaff MT, Leigh IM, Cerio R: Clinicopathologic features of skin cancer in organ transplant recipients: a retrospective case-control series. J Am Acad Dermatol $2006 ; 54: 290-300$. 
9 Fujimura T, Kambayashi Y, Hidaka T, Hashimoto A, Haga T, Aiba S: Comparison of Foxp3 ${ }^{+}$regulatory T-cells and $\mathrm{CD}_{163}{ }^{+}$macrophages in invasive and non-invasive extramammary Paget's disease. Acta Dermato-Venereol 2012; in press.

10 Viguier M, Lemaitre F, Verola 0, et al: Foxp3 expression CD4+CD25high regulatory $\mathrm{T}$ cells are overrepresented in human metastatic melanoma lymph nodes and inhibit the function of infiltrating T cells. J Immunol 2004;173:1444-1453.

11 Miroux C, Morales O, Ghazal K, Othman SB, de Launoit Y, Pancré V, Conti F, Delhem N: In vitro effects of cyclosporine $A$ and tacrolimus on regulatory T-cell proliferation and function. Transplantation 2012;94:123-131.

12 Tjiu JW, Chen JS, Shun CT, Lin SJ, Liao YH, Chu CY, Tsai TF, Chiu HC, Dai YS, Inoue H, Yang PC, Kuo ML, Jee SH: Tumor-associated macrophage-induced invasion and angiogenesis of human basal cell carcinoma cells by cyclooxygenase-2 induction. J Invest Dermatol 2009;129:1016-1025.

13 Fujimura T, Ring S, Umansky V, Mahnke K, Enk AH: Regulatory T cells (Treg) stimulate B7-H1 expression in myeloid derived suppressor cells (MDSC) in ret melanomas. J Invest Dermatol 2012;132:1239-1246. 